\title{
Narratives of Sustainability on Energy-Related Topics: Empirical Findings from German Geography Textbooks for Secondary Schools
}

\author{
Fabian PETTIG1 \\ University of Graz, Graz, AUSTRIA
}

\author{
Miriam KUCKUCK ${ }^{2}$ \\ University of Wuppertal, Wuppertal, GERMANY
}

${ }^{1}$ Corresponding author: Assist. Prof. Dr.; University of Graz, Faculty of Environmental and Regional Sciences and Education, Department of Geography and Regional Science, Heinrichstr. 36, Graz, AUSTRIA. fabian.pettig [at] uni-graz.at. ORCID: 0000-00022467-7468

2 Prof. Dr.; University of Wuppertal, School of Human and Social Sciences, Institute of Geography and Primary social and science education, Gaußstr. 20, Wuppertal, GERMANY. kuckuck [at] uni-wuppertal.de. ORCID: 0000-0002-3641-856X

\begin{abstract}
Previous analyses of German geography textbooks confirm tendencies towards the moralization of sustainabilityrelated content. Against this background, this study examines moralizations and normative implications of recurring sustainability narratives in German textbooks for secondary schools. From the sample of 15 current middle school textbooks from Thuringia and North Rhine-Westphalia, energy-related double pages $(n=106)$ were analyzed in terms of their surface and depth structures. The analysis focuses on the thematic and spatial references and the dimensions of sustainability, as well as on education for sustainable development (ESD 1 and ESD 2) and the transported narratives. The article concludes with the formulation of certain recommendations for action, to deal with energy-related topics in the sense of an emancipatory ESD 2, in both critical geography lessons and the design of educational media
\end{abstract}

\section{Keywords}

Energy; Sustainability Education; Narratives; Emancipatory Education; Geography Textbooks

To cite this article: Pettig, F.; Kuckuck, M. (2021). Narratives of sustainability on energy-related topics: empirical findings from German geography textbooks for secondary schools. Review of International Geographical Education (RIGEO), 11(2), 605-628. doi: 10.33403rigeo.810603 
Since the UN Conference on Environment and Development in Rio de Janeiro in 1992 , sustainability has been regarded as a guiding principle for action of the world society in the 21st century. Up until this conference, Environmental Education (EE) was mostly discussed with an emphasis on ecological perspectives. However, it was in Rio when this focus was extended with an economic and a social perspective, while focusing on sustainable development, too (Rieß, 2006, p. 9). This shift has led to the establishment of the normative educational concept of Education for Sustainable Development (ESD) which is, in an ongoing international debate, recognized, by some researchers, as a successor to EE (e.g. Bolscho \& Hauenschild, 2006) and as an additional approach next to EE by others (e.g. Pavlova, 2013). The aim of ESD is to enable people to "actively shape an ecologically compatible, economically efficient and socially just environment that takes global aspects into account" (BMBF, 2002, p. 4).

Bagoly-Simó $(2013,2014)$ examined the implementation of ESD in German education. Based on an analysis of the Bavarian middle school curricula of all school subjects, he found that ESD is thematically most comprehensively implemented in the subject of geography. A keyword search for the term "sustainable" in the titles or subtitles of journal articles, or the titles of practice-orientated journals in biology, politics, economics, social studies and geography from the period of the UN Decade of Education for Sustainable Development (2005-2014), supports this finding: for geography as a school subject, a "very strong and uniform implementation" of ESD is evident (Bagoly-Simó \& Hemmer, 2017, p. 15). A survey of German and Austrian pupils $(\mathrm{n}=1001)$ showed that the textbook is highly relevant for the implementation of ESD in concrete lessons (Kowasch \& Lippe, 2019). About one third of the interviewed pupils stated that they encountered the concept of sustainability or sustainable development in class mainly through the textbook. The authors conclude that "textbooks are the most common medium of instruction dealing with sustainability in school" (ibid., p. 1074). Even if this does not say anything about the current concrete actual handling of the contents of textbooks in the classroom, the relevance of the medium is clear.

Despite the importance of the medium for the success of ESD in everyday teaching, only a few analyses are available of the implementation of ESD in geographical educational media. Boehn and Hamann (2011) show that ESD in German textbooks is generally equated with the idea of environmental education. In their examination of 28 educational media from Bavaria, Lower Saxony, North Rhine-Westphalia and Saxony, the evident focus of the content was ecological aspects, while the facets of economy and social affairs remained underrepresented. Often, although no explicit instructions for action were formulated, it was evident that "doing without" was propagated. In an international comparative study on the subject of demographic dynamics as a topic of ESD, Bagoly-Simó (2013) clarifies the normative load of the 20 examined textbooks from Bavaria (Germany), Romania and Mexico and emphasizes the need to reflect on them: "In all cases, the Northern normativity of globally illegitimate growth in the South but legitimate growth in the North, which is featured in all textbooks, requires a more critical reflection" (p. 74). Kowasch (2017) comes to a similar conclusion in a study on the treatment of resources in 13 textbooks from Lower Saxony: "Most textbooks show a tendency to 
moralize development and sustainability issues. Along these lines, promoting sustainable development represents the 'good cause' and students have to be led to act and behave in a more sustainable way. In light of this, it seems highly likely that students experience a form of indoctrination" (p. 74). In a subsequent study, Kowasch and Lippe (2019) further elaborate on this aspect, having had explored the issue of raw material extraction in smartphone production in three textbooks from Germany and Austria. Here, too, it is evident that "textbooks also moralized sustainability issues" (p. 1074), and that they neglected complex global interrelationships and multi-perspective analyses.

In summary, previous studies of German and Austrian geography textbooks on ESD issues confirm tendencies towards the moralization of sustainability-related issues and the unreflecting handling of normative implications. In this empirical study, we pursue this particularly recurring finding and focus on energy-related ESD issues that, currently, have not been explicitly investigated. This observation, therefore, leads to the main research question guiding this study:

How do specific normative implications and moral charges of energy-related ESD issues appear in German textbooks for the middle school level?

To answer this question, we first of all concentrate on energy-related teaching content, which is of particular importance in global transformation. Hence, we highlight the ambivalence inherent in ESD between fulfilling an educational policy agenda and enabling educational processes, as well as the interwoven nature of ESD in different sustainability discourses. Since the subsequent content analysis of current textbooks from Thuringia $(n=9)$ and North Rhine-Westphalia $(n=6)$ for the lower secondary level reveals challenges in the design of geographical educational media on energy-related ESD topics, we conclude by elaborating perspectives for use in critical geography lessons.

\section{Energy (Transformation) and Global Transformation as an Object of ESD}

ESD, as an educational concept of geography lessons, is already entrenched in (almost) all curricula and textbooks in Germany. Even the German Society for Geography (DGfG) emphasizes that geography teaching is specifically committed to sustainable development (DGfG, 2020, p. 7). Boehn and Hamann (2011), in their analysis of textbooks, show that ESD primarily occurs as an implicit concept, and mainly in case of topics on tropical rainforest - renewable raw materials and resources, and sustainable urban development. Kuckuck and Lindau (2020), having had observed a total of 733 hours of geography lessons, found that ESD hardly ever occurs explicitly in class. To the extent that ESD is implicit in the classroom, it is mainly evident in topics such as agriculture, spatial disparities, coasts and waters, and migration movements. In Germany, up to the present, the teaching unit of energy and education for sustainable development has received little attention in geography lessons. Also, there has not been an explicit examination of the implementation of ESD in energy-related topics in German geography lessons.

In the ESD context, energy is an essential factor in a transformation to sustainability. A conclusion of the German Advisory Council on Global Change 
(WBGU, 2011) is that the major transformation towards sustainability is a consequence of global megatrends regarding system Earth, being severely threatened by mankind in the age of the "Anthropocene" (Crutzen \& Stoermer 2000, Crutzen 2002) or by exceeding the planetary limits (e.g. biodiversity) (Rockström et al., 2009). It is necessary to develop a lifestyle that corresponds with the model of sustainable global development. This demand applies to both developed and developing economies or countries. This lifestyle requires a transformation to sustainability since the natural foundations of life are endangered by the increasing world population. To shape this transformation, Agenda 2030 was adopted by all member states of the United Nations in 2015. For the first time, the 17 agreed upon goals of sustainable development considered all dimensions of sustainability: social, environmental and economic (BMZ, n.d.). Goal 7 on "Affordable and clean energy" one of the 17 goals - specifically focuses on energy and addresses the major importance of energy for economic interrelationships and developments. Energy is needed in all life and economic situations. National solutions are only limited approaches regarding energy supplies in a globalised world. Global interdependencies of energy flows are needed to be thought about with more efficiency. The "players" in this complex network include, amongst others, global players such as international corporations, political regulations and strategies, social framework conditions and, most recently, the end consumers. In addition, technical innovations are also needed to enable an energy turnaround for all. Above all, the transformation of energy systems also requires a transformation of society. The goals can only be achieved by switching to renewable energy sources and implementing strategies of energy sufficiency and energy efficiency (Schneidewind, 2019). A sustainable energy economy is based on energy sufficiency (a limitation of energy consumption for a given standard), energy efficiency (minimising energy consumption at constant output) and energy consistency (covering the energy demand with renewable energies). Germany is considered a pioneer in the transformation process of energy supplies. Therefore, energy, energy consumption, and energy saving are topics of the utmost social relevance especially for pupils. Not only is it a matter of learning to save energy and use it efficiently at home and at school, but it is also a matter of learning to understand the complex global interrelationships of the energy industry and energy supply. A way to experience sustainable consumption and a reflexive approach to consumer goods such as energy, in school, is to commit teaching to the Education for Sustainable Development approach.

For example, the geography curricula and syllabi of the federal states of North Rhine-Westphalia and Thuringia for middle school (grades 5-10) validate the major importance of sustainable development as a subject that teaches pupils how to shape the future (MSBL, 2019, p. 9). Sustainability is seen, amongst others, as a basic principle of human action that requires experienced subject competence from pupils (TMBWK, 2012, p. 8). The specific subject area of energy appears in the curricula of North Rhine-Westphalia, for example in content area 3, which deals with energy supply provided by industry and services. It can also be found in content area 5 , in which the conflict of climate protection goals and the goal of a secure and affordable energy supply is the subject matter of study (MSBL, 2019, p. 14f.). Energy is also represented in the curricula of Thuringia, which lists the providing of 
electricity from renewable and non-renewable energy sources (ibid., p. 14), the emergence of fossil fuels (ibid., p. 17), the development of the share of energy sources in energy generation (ibid., p. 17), and the development of the energy industry (ibid., p. 28) as teaching and learning content to be dealt with.

\section{Sustainability Education between Political Agenda and Maturity Orientation}

Within geography education discourses, the ESD approach has often been criticised. Hasse (2006, p. 40) points out that the development from environmental education to education for sustainable development does not represent a paradigmatic reorientation. Rather, it simply reproduces a number of problems that have been discussed for some time under new terminology, thereby phasing out previous discussions. For example, both approaches are based on an understanding of education that aims to impart knowledge for a specific purpose, namely to influence the actions of learners. From the perspective of education theory and pedagogy, the purpose relatedness of education is highly problematic. Even more recently, the fundamental criticism is that ESD is a normative-political concept rather than a notion motivated by education theory (Schuler \& Kanwischer, 2013). In particular, a tendency towards oversimplification can be seen in ESD concepts (Budke \& Gryl, 2016). Thus, on the one hand, conflicts of interest and power asymmetries are hardly considered, resulting in the danger of conveying simple solutions to complex global problems instead of initiating a multi-perspective understanding and awareness of their complex interdependence. On the other hand, agreement on the dimensions of sustainability is formulated as a utopian ideal of feasibility and its fulfilment is passed on to the individual. In other words, the responsibility for sustainable transformation is imposed on the individual as if, for example, only individual mobility or individual consumption has to change in favour of sustainable transformation (Danielzik, 2013). This is accompanied by the concealment of system-immanent, non-sustainable structures, due thereto that a focus on the symptom level neglects the understanding of complex backgrounds and suggests, instead, to adopt simple solutions and individual duties without fundamentally questioning the "premises of neoliberal growth ideology as the cause [...]" (Kehren \& Winkler, 2019, p. 379). As a result, it gets clear that there is a risk of moralising in the geography classroom that is geared to sustainability and action.

Because of its inherent normativity, ESD undeniably represents a complex challenge for teaching and learning. Marchand (2015, p. 141) puts it in a nutshell: "the question arises again and again where (legitimate) educational efforts turn into (illegitimate, though perhaps unintentional) attempts at indoctrination". The sustainability-related thematization of content in the classroom is thus inevitably situated in a field of tension inherent to ESD, which bridges the space between the implementation of an educational policy agenda and the enabling of emancipatory processes of subjectivation. However, in view of the current simultaneity of acute global challenges, as well as the educational mission of the school as an institution, a one-sided resolution of this field of tension might appeal expedient, but is not a rigorous solution. 


\section{Interdependent Dimensions of Sustainability Education}

Vare and Scott illustrated a possible way out of this dilemma by conceptualising the ambivalent problem horizon, outlined above, as two interrelated ESD dimensions:

We see ESD 1 as the promotion of informed, skilled behaviours and ways of thinking, useful in the short-term where the need for this is clearly identified and agreed, and ESD 2 as building capacity to think critically about what experts say and to test ideas, exploring the dilemmas and contradictions inherent in sustainable living. (Vare \& Scott, 2007, p. 191)

Wals et al. (2008) argue along similar lines and distinguish between instrumental and emancipatory approaches in sustainability education. In instrumental ESD 1, the focus lies on conveying expert knowledge on values and behaviour that are fundamentally recognised and linked to sustainable development (Vare \& Scott, 2007 , p. 192, Wals et al., 2008, p. 56). The aim is to promote behaviour that is deemed sustainable, and which ultimately leads to learning for sustainable development. By contrast, emancipatory ESD 2 enables a critical examination of sustainable development, including its associated complexity, uncertainty and contradictions (Vare \& Scott, 2007, p. 193f.). In this respect, Kehren and Winkler (2019, p. 381) emphasise that understanding the "historicity and policing of education, education, sustainability and the issues they negotiate" must be a central educational task of sustainable development. Therefore, global transformation also needs "a more systemic and reflective way of thinking and acting with the realization that our world is one of continuous change and ever-present uncertainty" (Wals et al., 2008, p. 57). Accordingly, sustainable development is understood as a learning process ("learning as sustainable development").

An emancipatory ESD 2 does not presuppose the prior teaching of an instrumental ESD 1, in the sense of prior learning of the hard facts or basics (Vare \& Scott, 2007, p. 195). It is also conceivable to develop critical perspectives in order to get to know sustainable development strategies (with all their contradictions and limitations). Therefore, the two main sides of ESD should not be regarded as cumulative, but as complementary. Using the Yin-Yang metaphor, Vare and Scott (2007, pp. 195-197) make it clear that both sides are interdependent and should be linked in educational contexts. Teaching that is exclusively committed to the mode of ESD 1 (e.g. by teaching instructions for action) or ESD 2 (e.g. by repeatedly questioning everything so that no option for action is regarded as meaningful) does not do justice to the matter. More recently, this discussion was also conducted under the heading of transformative learning (cf. Singer-Brodowski, 2016).

While we therefore acknowledge that institutional education in general and education for sustainable development in particular are normative, we also emphasise that education for sustainable development can only succeed if it is also understood as an emancipatory process that is always mindful of the normativity of sustainable development and its discursive interrelationships. 


\section{Narratives of Sustainability}

"Our common future", the title of the 1987 Brundtland Report on sustainability, introduced the concept of sustainable development to and published it amongst the world community. Sustainability is a normative term that unfolds according to its description (Rivera \& Nanz, 2018). Over the last three decades and probably also in future, this term has shaped and will shape both global negotiation processes and individual decisions. However, neither are the implicit and explicit narratives of the concept of sustainability frequently addressed, nor are the value orientations underlying them questioned. After all, language not only depicts the world, but always shapes it (Schlottmann, 2005, Felgenhauer, 2007). For example, socially conducted discourses on sustainability often focus on environmental sustainability, but rarely ever on social and economic sustainability, or on the conflicting goals of these three sustainability dimensions. Geography as a science and the subject of geography can play an important role in this regard, being the only subject that integrates the natural and social sciences in the classroom (Rhode-Jüchtern, $2004 / 2015$ ), thus revealing a unique, integrative approach and analysis of socially relevant, scientifically discussed discourses that are important for geography lessons.

Based on 100 interviews which they conducted with scientists from various disciplines, Rivera and Nanz (2018) identified several recurring sustainability narratives. For example, they showed that sustainable development is often accompanied by a strong normative orientation towards justice, and that many interviewees regard themselves as "helpers" who promote sustainable transformation. This narrative, in particular, is evident in respect of climate change and the consequences of climate change, and, in turn, is often produced by the use of concepts and attributions of blame by the Global North to the Global South. Rivera and Nanz (2018) also highlight the narrative of a real or fictitious "we" and an undefined "one", in that "we" have to rethink, act, etc., or that "one" has to do something. Who "we" or "one" are, remains unclear. Thus, without specifically ascribing it, an undefined "we" or "one" determines that responsibility is a subject of discussion, with the consequence that no one feels addressed. Another narrative depicts the position of the "anti-hero" or "villain". According to this narrative, blame is often channelled to 'politics' or individual politicians, or to 'the economy' or individual economic actors, with the result that it often remains superficial.

In addition to these narratives, there are certainly other narratives on sustainable development in different contexts that, thus far, have hardly been addressed. There has, however, been no investigation of exactly which narratives occur in geography lessons or in geography textbooks. Nonetheless, the omnipresence of these discourses is a clear indication of their importance for geography lessons. Therefore, teachers should clarify that geography must be understood as "one" discourse among many (Steffens, 2010), and should point out gaps or blind spots in the subject, as well as the finiteness and limitations of scientific findings. The validity of knowledge is limited, and specific knowledge should not be regarded as an irrevocable fact. The conditions of validity of knowledge are always bound to time and space. Kuckuck (2014) demonstrated the importance of language and communication for and in geography lessons, by pointing out narratives on spatial 
conflicts as a topic of geography lessons. It is necessary to indicate and deconstruct these widespread and repeatedly produced explanations of the world in the classroom, by asking who is referring to what and with what intention. Also, these discourses always imply, directly or indirectly, instructions for action (e.g. to minimise or solve environmental problems, to change one's own actions, to stop buying certain things, etc.).

\section{Questions of the Study}

The guiding question posed at the outset, "How do specific normative implications and moral charges of energy-related ESD issues appear in German textbooks for the middle school level?" is further subdivided and differentiated on the basis of the preceding theoretical foundation. In the empirical section, we pose the following questions:

- On the basis of which topics and regional examples does energy become an object in the textbooks?

- Which dimensions of sustainability (social, economic, environmental) or education for sustainable development (ESD-1 and ESD-2) are conveyed in the textbooks?

- How do which narratives or normative implications become visible in the thematic content of the textbooks?

- Which principles of action can be derived from these insights?

\section{Methodology}

\section{Sample of the Study}

In the context of this study, we examined German textbooks for secondary schools from Thuringia (TH) and North Rhine-Westphalia (NRW). The most recent editions of the three largest textbook publishing houses, Cornelsen, Klett and Westermann, available at the time of the study, were considered for each federal state. Since textbooks are designed for two-year cohorts, the publishers have three textbooks for the lower secondary level in each of the two states, that is nine books per state. This study has examined nine books from TH and six books from NRW (see appendix).

Not only is this selection related to the authors' places of work, but it also provides the opportunity to take into account the widest possible range of educational media currently in use in secondary schools in Germany. This rationale is justified by the fact, on the one hand, that the study includes the largest old federal state (NRW) and the second-smallest new federal state (TH) ${ }^{1}$. On the other hand, the most recent Thuringian textbooks are several years old and the North RhineWestphalian textbooks are currently being updated and, correspondingly, have more recent publication dates. At the time of this study, not all books from NRW 
were available in their updated version. As a result, we excluded the remaining three textbooks for grades $9 / 10$ of the three publishers (NRW) in their currently available, non-updated form. This decision was taken because we assume that the biggest differences are not between the federal states but between the updates. We also point out that the comparative analysis of textbooks is not the focus of the present study. Rather, we expect our approach to present the broadest possible picture of the way in which energy-related issues are currently being debated in German middle schools. Admittedly, a limiting factor is that the selected sample is not representative.

\section{Data Collection and Data Analysis}

Overall, despite the major importance of energy, only a few pages cover energyrelated topics. Thus, a preliminary analysis identified 106 double pages with an energy reference from the entire body of material, which were subsequently examined in more detail in this study. Since the double pages represent coherent sections of meaning, each double page was considered a unit of investigation in the analysis. As an additional service, all textbook publishers make supplementary material available online. Since it cannot be assumed that this material is always used along with the double page in the classroom, partly due to the limited availability of technical equipment in many German schools, this study excluded an analysis of the additional material. The identified pages were scanned and made available for joint analysis and collaborative work in a cloud, so that each of the authors had access to all entities of the analysis. The material was examined inductively-deductively by means of qualitative content analysis (Mayring, 2000), more explicitly in a scaling and structured manner (Gläser-Zikuda, 2013). In a circular process of analysis, individual sections of meaning were assigned to deductively formed categories in a first step. In a subsequent step, categories were added inductively and these were used in further rounds to analyze the material. Due to the Covid19-pandemic, the discursive evaluation of the material took place virtually. Microsoft Office was used for software-assisted analysis.

To answer the first research question, the themes were obtained inductively and deductively from the data material. First, all themes were listed and then summarized in a connected process. This process results in a total of seven categories (inductive: anthropogenic climate change, technical topics/overview topics, spatial conflicts, transformation; deductive: energy consistency, energy sufficiency, energy efficiency). In addition to grade, the scale of the topics was collected. In order to examine the global interconnectedness and complexity of energy issues as shown in the theory section.

To answer the second research question, the material was examined in relation to the three dimensions of sustainability (environmental, economy, social) as well as the underlying dimension of ESD. The following rules of analysis were applied in the first step: Environmental (i.e. environmental protection, effects on the environment ...); Economy (i.e. economic impacts, economic development ...); Social (i.e. impact on the population, perspectives of residents ...). One double page could be assigned to more than one dimension of sustainability. For this purpose, the relevant texts (authors' texts, tasks, additional material) and the 
illustrations/graphics (maps, photographs, diagrams, caricatures) were examined in relation ESD I and ESD II, using a qualitative scaling data analysis (see Table 1).

Table 1

Category system, scaling data analysis on ESD 1 and ESD 2

\begin{tabular}{|c|c|c|}
\hline Variable & Definition & Examples \\
\hline ESD 1 & $\begin{array}{l}\text { focus on expert } \\
\text { knowledge of SD } \\
\text { conveying values that } \\
\text { are commonly } \\
\text { recognized and } \\
\text { linked to SD } \\
\text { tasks that foster } \\
\text { sustainable behavior }\end{array}$ & $\begin{array}{l}\text { "Checking the effects of your own lifestyle on the } \\
\text { earth" (NRW6, p. 92) } \\
\text { "Find possibilities for saving CO2 [in everyday } \\
\text { life]" }\end{array}$ \\
\hline ESD 2 & $\begin{array}{l}\text { critical examination } \\
\text { of SD (contradictions, } \\
\text { complexity, } \\
\text { uncertainty) } \\
\text { addressing the } \\
\text { normativity of (E)SD } \\
\text { tasks that foster } \\
\text { critical thinking }\end{array}$ & $\begin{array}{l}\text { "One of the largest consumers worldwide is } \\
\text { Germany. In addition to plant and animal } \\
\text { agricultural raw materials, it is primarily mineral } \\
\text { and thus non-renewable industrial raw materials } \\
\text { that every German citizen consumes in large } \\
\text { quantities. Only a small proportion of the raw } \\
\text { materials comes from domestic production. Most } \\
\text { raw materials have to be imported to Germany (...)" } \\
\text { "A sustainable approach to raw materials that } \\
\text { replaces the current way of using resources is } \\
\text { therefore urgently needed to preserve habitats for } \\
\text { future generations. The following sustainability } \\
\text { strategies are being discussed: } 1 \text {. higher efficiency } \\
\text { (...), 2. environmentally compatible production, } \\
\text { transport and consumption (...), 3. reduction of } \\
\text { demand for goods and energy (...)". }\end{array}$ \\
\hline
\end{tabular}

Rules of analysis: An assignment to ESD1 or ESD2 is made if at least 2 of the defined criteria are fulfilled on a double page. A double page could either be assigned to none, one or both dimensions.

To answer the third research question, we conducted a qualitative content analysis (Mayring, 2000). Following the research of Rivera \& Nanz (2018), who interviewed 100 experts on sustainability to elaborate narratives, we deductively formed and inductively added the following narratives and examined the material in this regard (see Table 2). 
Pettig, F.; Kuckuck, M. (2021). Narratives of sustainability on energy-related topics: empirical...

Table 2

Category-system, structured data analysis on narratives of sustainability

\begin{tabular}{|c|c|c|c|}
\hline \multicolumn{2}{|c|}{ Category (Narrative) } & Definition & Examples \\
\hline \multirow{3}{*}{ 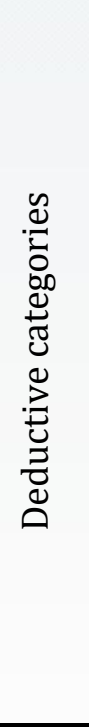 } & $\begin{array}{l}\text { (Abstract) } \\
\text { personalization }\end{array}$ & $\begin{array}{l}\text { An unknown "we" and/or } \\
\text { "one" are addressed. }\end{array}$ & $\begin{array}{l}\text { "What can we do?" (NRW2, p. } \\
\text { 162) } \\
\text { "Let's do it!" (NRW2, p. 152) }\end{array}$ \\
\hline & Injustice and blame & $\begin{array}{l}\text { Abstract agents are } \\
\text { addressed (the politics, } \\
\text { the economy ...) as the } \\
\text { source of global } \\
\text { inequalities. }\end{array}$ & $\begin{array}{l}\text { "The world's hunger for } \\
\text { energy is growing. (...) The } \\
\text { world can cope with seven } \\
\text { billion people with the } \\
\text { demands of an African - not } \\
\text { with seven billion people } \\
\text { with the demands of a } \\
\text { German." (TH5, p. 66) }\end{array}$ \\
\hline & $\begin{array}{l}\text { Heroes and anti- } \\
\text { heroes }\end{array}$ & $\begin{array}{l}\text { A distinction of good and } \\
\text { bad players is made on } \\
\text { different scales (countries, } \\
\text { stakeholders ...) }\end{array}$ & $\begin{array}{l}\text { "In } 1986 \text {, the world's worst } \\
\text { reactor disaster occurred in } \\
\text { the Ukrainian Chernobyl and } \\
\text { has claimed over a million } \\
\text { lives to date" (TH6, p. 66). }\end{array}$ \\
\hline \multirow{2}{*}{ 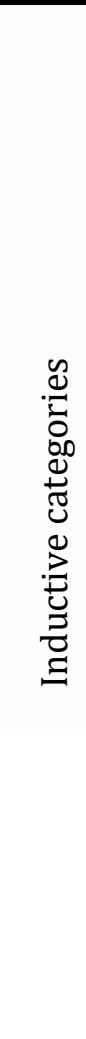 } & Disequilibrium & $\begin{array}{l}\text { Focus on certain aspects of } \\
\text { SD while neglecting } \\
\text { others. }\end{array}$ & $\begin{array}{l}\text { "If coal is no longer mined, an } \\
\text { open-cast mine must be } \\
\text { recultivated according to the } \\
\text { law. The destroyed landscape } \\
\text { is restored so that it can } \\
\text { either be used for agriculture } \\
\text { or forestry or it is converted } \\
\text { for recreational purposes. } \\
\text { This is what is happening in } \\
\text { the Lusatian and Central } \\
\text { German mining districts in } \\
\text { particular" (TH2, p. 144) }\end{array}$ \\
\hline & $\begin{array}{l}\text { Growth and } \\
\text { protection }\end{array}$ & $\begin{array}{l}\text { SD as balancing act } \\
\text { between economic growth } \\
\text { and environmental } \\
\text { protection }\end{array}$ & $\begin{array}{l}\text { "Since most countries of the } \\
\text { world are dependent on the } \\
\text { import of this coveted raw } \\
\text { material, the volume of } \\
\text { transport is constantly } \\
\text { increasing. Unfortunately, } \\
\text { accidents can never be } \\
\text { completely ruled out. But the } \\
\text { associated dangers for the } \\
\text { environment are } \\
\text { considerable" (TH5, p. 60) }\end{array}$ \\
\hline
\end{tabular}

Rules of analysis: An assignment is made when the defined criteria is fulfilled. A double page could be assigned to several categories.

To answer the fourth research question about the principles of action, the results of the three previous questions were summarized and interpreted. 


\section{Limitations of the Study}

Since only textbooks from two states in Germany and here only from the Gymnasium (academic high school in Germany) were selected, the results are not representative for all textbooks in Germany. Nevertheless, with our explorative study we can give an insight into the thematization of energy-related topics and sustainability in German geography textbooks. Despite a qualitative approach, data was repeatedly checked in a circular process, so that a high reliability is achieved. In further steps, other educational materials should be investigated. A comparison with textbooks from other countries could also provide insightful information here.

\section{Findings}

\section{Thematic and Spatial Dimensions of Energy-Related Learning Objects}

Six thematic areas could be highlighted in the analysis: Anthropogenic climate change, technical topics/overview topics, spatial conflicts, transformation, energy consistency, energy sufficiency, energy efficiency. Whereby the majority of the examined double pages deals with technical topics or overview topics. This category mainly includes purely introductory pages, e.g. on the formation of coal, the structure of an opencast lignite mine or how a wind turbine works. These topics relate primarily to local or regional examples of space and are addressed in grades 5 and 6.

It is evident that the sustainable transformation topics are hardly ever addressed in the textbooks. There are isolated references to energy sufficiency and energy efficiency in the North Rhine-Westphalian and Thuringian textbooks. For example, a textbook states: "In order to be able to cover the demand for raw materials, more and more resources must be used (...). The following sustainability strategies are discussed: "Higher efficiency (...), environmentally friendly production, transport and consumption (...), reduction of the demand for goods and energy (...)" (TH9). Energy consistency is addressed in the few examples of the energy cycle, amongst others in the case of biogas plants. The topic of necessary transformation is introduced with reference to the change in the mining area of lignite, since the decision was previously made to phase out coal and, as a result, the landscapes have already undergone major transformations and will continue to do so in future. By contrast, the issue of a comprehensive rethinking process in the energy sector is not addressed. Increasingly, spatial conflicts can be identified in Thuringian textbooks for grades 9/10, especially those which offer global spatial references. However, hardly any reference is made to regional or even local spatial conflicts in Germany.

A comparison of the spatial references of energy-related topics shows that the regional and local references are highest in the lower age groups. This observation is particularly evident in the North Rhine-Westphalian textbooks, representing over $80 \%$ of the pages. In this case the focus on the local area is also determined by the choice of the topic (the mining of lignite). Examples from non-European countries are exclusively used in higher grade textbooks. This trend is particularly evident in Thuringian textbooks. By contrast, European spatial examples are less evident in the studied textbooks. 
Pettig, F.; Kuckuck, M. (2021). Narratives of sustainability on energy-related topics: empirical...

Global connections in the energy sector, (globally acting) actors, power constellations and dependencies, on the other hand, are not addressed. Energy is mainly presented as a local/regional problem in the textbooks considered. It has also become clear that the antiquated principle of geography education "from near to far" is still present in the textbooks studied (Fridrich, 2013). Since only in the higher grades global topics are addressed, whereas in the lower grades the local/regional reference dominates.

\section{Environmental, Economic, and Social Dimensions of Energy-Related Learning Objects}

The majority of the double pages examined relate to at least one of the three dimensions of sustainability (85\%); the remaining cases include illustrations of technical processes (e.g. coal mining). Regarding their detail, it is evident that energy-related topics are usually dimensioned economically (78\%) or environmentally (65\%). The social dimension of sustainability is far less evident (32\%). Environmental and economic perspectives are most frequently interlinked (58\%); the interweaving of environmental, economic, and social concerns is found in approximately a quarter of the energy-related double pages (25\%). However, individual aspects are often treated superficially. In an example, energy transformation in Germany is discussed primarily on the basis of the environmental and economic advantages and disadvantages of nuclear energy, and the social implications of this process are only marginally visible in a small photo of a demonstration against nuclear energy without any noticeable reference to the information texts or the tasks (TH7, pp. 148-149). By contrast, the economic and social (5\%) dimensions, as well as the environmental and social dimensions (1\%) are hardly intertwined.

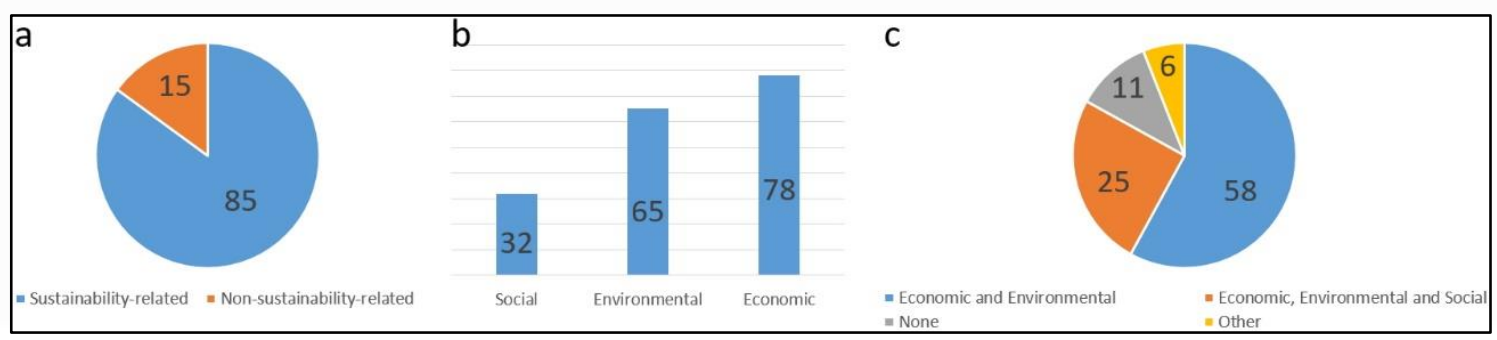

Figure 1. [a] Relatedness to sustainability on energy-related topics; [b] Dimensions of sustainable development on energy-related topics; [c] Interconnectedness of sustainability dimensions on energy-related topics; $(n=106)$ (all information as a percentage)

The Thuringian textbooks for 2012-2015, in comparison, differ in some respects from the textbooks that have been updated in NRW since 2019. While it is apparent in the more recent North Rhine-Westphalian textbooks that in more than half the cases energy-related phenomena are simultaneously addressed from an environmental, economic and social perspective (56\%), this occurs less frequently in the older Thuringian textbooks (19\%). Compared with and in contrast to the North Rhine-Westphalian textbooks (11\%), the intertwining of the economic and ecological dimensions of energy-related phenomena predominates in Thuringian textbooks (41\%). 


\section{Dimensions of Sustainability Education}

The analysis shows that about half of the double pages examined on energyrelated topics (53\%) are essentially used for the simple transfer of specialist knowledge. An example of this is the presentation of scientific processes or technical procedures, when presenting geological stratifications or possibilities for mining lignite (NRW5, pp. 106-107). However, this example includes the discussion of the advantages and disadvantages of renewable energies, as well as the determination of optimal locations for wind or hydro-electric power plants, without critical distance to the sustainability-related implications of the contents (TH7, pp. 150151). It is noticeable that the comparison of the advantages and disadvantages only raises the problem of high costs and impacts on ecosystems. Although these double pages can be classified as energy and sustainability-related, there is at the same time neither a recognisable multi-perspective thematization nor a development perspective inherent in the contents. In other words, due to the lack of a presentation of the overarching problem contexts that integrate the knowledge, the content is not directly aimed at sustainable development and thus does not correspond to ESD in a more specific sense.

By contrast, on the remaining half of the double pages examined, the content is prepared in the field of ESD 1 (45\%). Thus, several textbook pages directly address the pupils and aim to develop an awareness of climate protection and to indicate possibilities for action in everyday life. For example, at a point it is about "checking the effects of your own lifestyle on the earth" (NRW6, p. 92). Specifically, as a first step, pupils are required to calculate their personal $\mathrm{CO} 2$ balance by means of a $\mathrm{CO} 2$ calculator on the basis of the parameters of eating behaviour, locomotion and consumption and, as a second step, to "find possibilities for saving CO2 [in everyday life]" (ibid., p. 93). Not all double pages assigned to this category explicitly aim for developing possibilities for action in the classroom, and implementing them in everyday life. Often, simply the finiteness of fossil resources and the consequences of fossil-fuel combustion are presented in relation to climate change, followed by an emphasis of the need to "reduce the emission of carbon dioxide into the atmosphere" (TH2, p. 222), which also implies changes in individual behaviour. Renewable energies are usually discussed as having no alternative, by not reflecting on either the unsustainable implications of renewable energies, that is the use of rare earths such as Dysprosium and Neodymium, in the production of wind turbines, or on the social and environmental impacts thereof in the mining regions of China and Mongolia (Rüttinger et al., 2014).

Only two of the textbook pages examined, at least to some extent in the sense of ESD 2, address the ambivalences, gaps and unresolved issues associated with sustainable development (2\%). For example, a double page on the topic of raw materials presents Germany as one of the largest global consumers of raw materials, but makes it clear that most raw materials must be imported (TH3, p. 50). This suggests, at least implicitly, that the high standard of living in Germany is also linked to unsustainable conditions for the extraction of raw materials in other locations and is thus integrated into unsustainable global structures. In the presentation of different sustainability strategies, the need for change of lifestyles or consumption patterns in the developed countries is also briefly clarified (ibid., p. 51). A second 
double page is dedicated to the local example of the planned construction of a highvoltage power line through Großbreitenbach in Thuringia (TH9, pp. 192-193). In specific terms, the arguments of the network operators and their opponents must be worked out based on information texts. Then, the arguments have to be presented and debated in the classroom. It is evident, based on the different lines of argumentation, that the politically desired and socially supported energy transformation also requires the transport of electricity from renewable sources, for example wind energy from northern Germany over long routes to southern Germany, where most of the energy is required. These routes are also associated with environmental, economic, and social problems. In specific terms this understanding means that the implementation of energy transformation also involves non-sustainable partial steps. Here lie at least two potentials: First, to uncover the contradictions of sustainable development and second to reflect on them in a multi-perspective manner.

\section{Narratives and Normative Implications of Energy Related Learning Objects}

The production and publication of textbooks are embedded in specific conditions of origin, which is the existing structural framework, the state of knowledge at the time of production and the prevailing social discourses. In the individual German states, the approval of textbooks is subject to a series of procedures before they will be delivered to and can be used in schools. In terms of content and structure, they must conform to the curricula and guidelines of the respective federal states and be compatible with the constitution of the Federal Republic of Germany, be abreast of the latest scientific knowledge, and enable children and young people to follow individual learning paths (MSJK, 2003). Accordingly, explicit and hidden narratives, as well as normative implications in textbooks must be understood prior to the aforementioned conditions of origin.

Narrative I: (Abstract) personalization of "we" and "one". "Let's do it!" (NRW2, p. 152) and "Improve energy use?! - What can we do?" (ibid, p. 162) are the titles of two double-page spreads. Another title also reads, "Anyone can do something" (ibid). These phrases imply, on the one hand, that a prevailing problem can or must be solved and, on the other hand, that everyone can and should contribute something. At these textbook pages, the narrative that everyone must participate in the process of transformation is strongly represented. However, the "we" and the "one" are not clearly defined. The learners should feel addressed and get to know different methods of energy efficiency and conservation. At another textbook page, the learners are addressed directly in the title that asks the question: "What can I do?" (ibid, p. 164). Here, too, a mandate for action is clearly suggested. The learners, supposedly as competent homeowners and tenants, are shown how and where they can save electricity. Furthermore, they are required to use CO2 calculators to calculate their own $\mathrm{CO} 2$ balance, and to compare their results with other countries. Another task, for example, is to "Think globally, act individually climate protection works best in everyday life. Discuss" (NRW6, p. 92). In this case, abstract personalisation is also abandoned, and the students are directly addressed as participants and encouraged to actively participate in the process of energy transformation. 
Narrative II: Injustice and blame. "The world's hunger for energy is growing. (...) The world can cope with seven billion people with the demands of an African not with seven billion people with the demands of a German." (TH5, p. 66). This example, quoted from a textbook, illustrates how the links between the demand for energy and economic status, in the countries of the global North and the global South respectively, are often presented. The "hunger for energy" of growing economies, such as China, India, and Brazil, is often mentioned. Also, current structures in currently industrialising and developing countries are justified, amongst others, by colonisation. "With 162 million inhabitants, Nigeria is the most populous country in Africa. Today's state structure is a result of the colonial era. The British established the borders without regard to the people who live there (...)" (TH2, p. 144). The more developed states are, the greater is their impact on anthropogenic climate change and on the dependence of the so-called 'underdeveloped' on the developed economies and countries of the global North. Similarly, regarding energy issues, blame is specifically apportioned to the emerging economies and countries, which are catching up with the industrialised countries and thus require huge amounts of resources. The fact that this catching up is necessary to advance a sustainable transformation in the sense of SDGs, is not addressed in the textbooks.

Narrative III: Anti-heroes and heroes. The attribution of the anti-hero is also striking in German textbooks, as is the glorification of heroes in the context of energy and sustainability. In a textbook section on environmental problems in Russia, the expulsion of guilty parties is clearly evident. It says, for example: "Although such [environmental] problems exist worldwide, they hardly ever occur anywhere as massively as in Russia and the other successor states of the Soviet Union" (TH6, p. 66). Further on the text reads: "In 1986, the world's worst reactor disaster occurred in the Ukrainian Chernobyl and has claimed over a million lives to date" (ibid.). In this 2014 textbook, Russia and the successor states of the Soviet Union are still attributed blame for a great deal of environmental pollution and are portrayed as the worst polluters in the world. The reactor catastrophe following the tsunami in Fukushima (Japan) in 2011 is not mentioned at all.

Heroes, however, are also created in textbooks. For example, when it comes to energy transformation and the expansion of renewable energies, future projects or individual countries are highlighted. The Deserted project is a case in point, being presented as an initiative to transport solar energy from the Sahara to Europe, and to satisfy the energy demands of Europe by using solar energy from the Sahara (TH5, p. 69). In many textbooks, Germany is considered a pioneer and a role model in energy transition and the expansion of renewable energies: "Germany wants to generate less electricity from lignite in the future to protect the environment" (NRW1, p. 112). Domestic solutions are often presented in textbooks. In addition to depicting Germany as a pioneer of energy transformation, Russia (see above), Nigeria and China are presented with reference to their (environmental) problems, dependencies, and conflicts. The fact that the electricity grid and trade in electricity is a European solution, is hardly discussed. In a textbook, the European power grid is briefly dealt with, whereas the text itself formulates the verbs in the subjunctive as if this is a future prospect. "In the European Union, the secure supply of electricity is being sought across borders. This would improve the living conditions for all EU 
citizens. The economy and transport systems would also be less vulnerable to bottlenecks (...)" (TH2, p. 152). This phrase suggests an option for the future, but it is already a current reality.

Narrative IV: (Dis-) equilibrium of the ESD dimensions. Having previously described, the three dimensions of sustainability (environmental, economic, social) are represented to varying degrees in textbooks. Only $25 \%$ of the examined textbook pages deal with all three dimensions simultaneously. The fact that all three dimensions can never be referred to in the same way, and that the pursuit of one dimension is at the expense of at least one other dimension, remains open for discussion in textbooks. Frequently, highly perilous spatial conflicts are presented in textbooks as being completely free of conflict. For example, a textbook presents the mining of lignite in open-cast mines without dissent, where it says: "If coal is no longer mined, an open-cast mine must be recultivated according to the law. The destroyed landscape is restored so that it can either be used for agriculture or forestry or it is converted for recreational purposes. This is what is happening in the Lusatian and Central German mining districts in particular" (ibid., p. 144). Social discourse, problems and conflicts are not addressed and remain blind spots of the textbook narrative. Nor does the mining of coal, in this example, seem to pose any problems. Neither ecological nor social negative consequences of coal mining are discussed.

The conflict over lignite mining, that exists between the three dimensions of sustainability, is not discussed by the pupils. On another textbook page, Siberia is presented as a treasure trove of oil and gas production. A map is used to locate the resources, along with a description of the history of production. Again, the consequences of production and transport are pictured as being completely free of conflict. Environmental problems seem to be non-existent. On the contrary, production is portrayed as having many positive consequences, for example for the population. In the textbook it is stated: "New, modern cities have emerged in Western Siberia: Surgut, Khanty, Mansiysk and others. Thanks to the revenues from the gas and oil business, they offer modern housing, good utilities and a wide range of leisure activities for their inhabitants compared to other industrial cities in Russia" (TH3, p. 66).

Narrative V: Sustainable development between economic growth and environmental protection. Sustainability is emphasised in all of the textbooks sometimes more and sometimes less explicitly - as a necessary guiding principle of global development. At the same time, and in most cases, the implementation of sustainable development is addressed as a balancing act between economic growth and environmental impacts. As a rule, growth is presented as a scenario without an alternative, because "economic growth means prosperity" (TH3, p. 64).

This narrative is illustrated by the example of handling mineral oil, to which several pages are dedicated in all textbooks: "Since most countries of the world are dependent on the import of this coveted raw material, the volume of transport is constantly increasing. Unfortunately, accidents can never be completely ruled out. But the associated dangers for the environment are considerable" (TH5, p. 60). Environmental disasters, such as the one caused in 2010 by the accident of the oil 
rig "Deepwater Horizon", are often negotiated solely as a problem of technical feasibility. Experts would say that, in this case, the safety regulations were not observed because "the existing technology is not sufficient for drilling at such great depths" (ibid., p. 61). The importance of the raw material for everyday life is also emphasised in this context; products made from oil are thus an indispensable part of everyday life. Tasks also aim at indicating "the importance of petroleum for your daily life" (ibid.). Technological innovations are presented as a way out of the dilemma of increasing global energy consumption and the simultaneous finite nature of fossil fuels. For example, "with the help of improved extraction technologies", new raw material deposits would have to be developed to counteract the shortage of raw materials (TH3, p. 65). The use of renewable alternative products, recycling or more efficient production methods are also cited as ways to meet the growing demand for raw materials (ibid.).

In contrast, the possibility of alternative social and economic guiding principles, which do not aim at unlimited growth, is not discussed. The planetary boundaries as a starting point for global rethinking are at best implicitly elaborated. For example, one can identify this observation when the overuse of biological resources of ecosystems and the exceeding of their natural regenerative capacity are pointed out as "overexploitation" (ibid., p. 73).

\section{Result and Discussion}

The aim of this study has been the examination of topics of energy with their spatial references, the dimensions of sustainability and an education for sustainable development as well as normative implications and moral charges on energyrelated topics in German textbooks for secondary school students. From the sample of 15 current textbooks from Thuringia and North Rhine-Westphalia, a total of 106 double pages were analysed with regard to their surface and depth structures. Even though the sample can be classified as non-representative, the inductive-deductive procedure has proved to be extremely productive and it has shown clear trends in the material. Thus, the study has shown that the topics are mainly pure overview topics presented at the local level. In contrast, topics of an energy transition or transformation, as they have been discussed socially in Germany for a long time, appear rather rarely (WBGU, 2011, Schneidewind, 2019). The outdated teaching principle from the "near to the far", on the other hand, is still followed in textbooks (Fridrich, 2013).

Furthermore, it became apparent that energy-related topics were often discussed on a superficial level without reflecting implications for sustainability on a local or global scale. If ESD could be discerned as an underlying principle of a double page, there was a clear trend in the material to aim at fostering sustainable behavior (ESD 1) rather than fostering critical reflection on sustainability/sustainable development and its inherent contradictions, global structures of unsustainability etc. (ESD 2). This lines up with Hasse's (2006) critique of an ESD that primarily aims to influence the action of learners rather. Furthermore, these findings line up with other studies that have shown a tendency of neoliberal and instrumental approaches in institutionalized ESD (Selby \& Kagawa, 2010). 
When elaborating the narratives, the normative implications in textbooks became obvious. On the few textbook pages on which the energy transition is discussed, the students are directly addressed as actors. The socially distributed narrative that everyone can do something about climate change is also found in the textbooks. Students learn or are asked to act in the areas of energy sufficiency and efficiency. Addressing this through personalization involves everyone (Rivera \& Nanz 2018). This addressing is also clear in depicted inequities, accusations and blame (Narrative II). The distinction between developed and non-developed countries, as well as explanations of the colonial era, highlight the dichotomization of the global North and South. In addition to guilt, school textbooks also produce heroes or anti-heroes (Narrative III). The narrative of disequilibrium (IV) has made it clear that the dimensions are in conflict with each other, as they can never be considered equally. This lack of consideration leads to conflicts, which are recognizable in society. In the textbooks, however, spatial conflicts are hardly presented in their conflictual nature. If conflicts are presented, they can be found between the economic and ecological dimension. Narrative (V) also emphasizes the dichotomy between economic growth and environmental protection. Sustainable development is considered the leitmotif of global development. Alternatives to economic growth or limits to growth are not discussed.

Subsequently, several central findings of the empirical study are summarized in detail:

- Energy-related issues are mainly discussed as local, regional, or national problems; global interdependencies of the energy industry and of local energy supply play a secondary role.

- Individual changes in behavior are at the forefront of energy-related sustainability; structural non-sustainability is not addressed.

- In energy-related topics, sustainability is predominantly equated with environmental sustainability while maintaining economic growth; the social dimension of energy-related sustainable development is underrepresented.

- Energy-related sustainable development is based on the ideal of economic growth; alternative economic guiding principles, or the possibility of a fundamental rethink for society as a whole, are not discussed.

- Technological innovations are presented as a way of securing resources; alternative lifestyles are not discussed.

Against this background, we conclude by proposing three recommendations to deal with energy-related issues in the sense of an emancipatory ESD 2; both in critical geography lessons and in the design of educational media.

- Deconstruction of sustainability discourses and implicit narratives through multi-perspective and critical approaches (the juxtaposition of macro and micro perspectives, the tracing of divisive lines of argumentation and actors).

- Thematization and reflection of non-sustainable (global) structures, for example the normative (environmentally compatible) ideal of growth (here: 
green growth), and the identification of sustainable alternatives and lifestyles (here: degrowth).

- Interweaving of lifeworld significance and global interdependencies of energyrelated topics in order to stimulate an in-depth discussion of sustainable development.

Using the example of energy-related topics, this study made it clear that in German geography textbooks the topic of sustainability is either treated in an unreflective manner or mostly equated with sustainable growth. However, in view of the strain as well as the imminent and irreversible overshooting of planetary boundaries, it becomes abundantly clear that geography education needs to more intensively consider alternative scenarios in order to step out of a "business as usual" and prepare pupils for the challenges of the 21st century.

\section{Acknowledgement}

We are grateful to the publishing houses Cornelsen, Klett and Westerman for providing the textbooks analyzed in this study. Furthermore, we thank Nicola Richter and Felix Freymann for their contribution during data collection.

\section{References}

Bagoly-Simó, P. \& Hemmer, I. (2017). Bildung für nachhaltige Entwicklung in den Sekundarschulen - Ziele, Einblicke in die Realität, Perspektiven. Retrieved from https://www.ku.de/fileadmin/150305/Professur_fuer_Didaktik_der_Geographie/F orschung/Literatur/Bildung_f\%c3\%bcr_nachhaltige_Entwicklung_in_den_Sekundars chulen_\%e2\%80\%93_Ziele_Einblicke_in_die_Realit\%c3\%a4t_Perspektiven__Bagoly-Simo__Hemmer.pdf

Bagoly-Simó, P. (2013). Dealing with Growth: Population Dynamics and (Un)Sustainability in Geography Textbooks. RIGEO, 3(1), 56-76.

Bagoly-Simó, P. (2014). Implementierung von BNE am Ende der UN-Dekade. Eine internationale Vergleichsstudie am Beispiel des Fachunterrichts. Zeitschrift für Geographiedidaktik - Journal of Geography Education, 42(4), 221-256.

BMBF (Bundesministerium für Bildung und Forschung). (2002). Bericht der Bundesregierung zur Bildung für nachhaltige Entwicklung. Retrieved from https://www.globaleslernen.de/sites/default/files/files/link-

elements/bundesregierung_20zur_20bildung_20f_c3_bcr_20eine_20nachhaltige_20e ntwicklung_2c_202002.pdf

BMZ (Bundesministerium für wirtschaftlichen Zusammenarbeit und Entwicklung). (n.d.). Die Agenda 2030 für nachhaltige Entwicklung. Retrieved from http://www.bmz.de/de/themen/2030_agenda/index.html

Boehn, D. \& Hamann, B. (2011). Approaches to sustainability. Examples from geography textbook analysis in Germany. European Journal of Geography 2(1), 6-14.

Bolscho, D. \& Hauenschild, K. (2006). From environmental education to Education for Sustainable Development in Germany. Environmental Education Research 12(1), 7-18. doi: $10.1080 / 13504620500526297$

Budke, A. \& Gryl, I. (2016). Bildung für nachhaltige Entwicklung - zwischen Utopie und Leerformel? Potentiale für die Politische Bildung im Geographieunterricht. In A. 
Pettig, F.; Kuckuck, M. (2021). Narratives of sustainability on energy-related topics: empirical...

Budke \& M. Kuckuck (Eds.), Politische Bildung im Geographieunterricht (pp. 57-75). Stuttgart: Franz Steiner Verlag.

Crutzen, P. \& Stoermer, E. (2000). The "Anthropocene". Global Change Newsletter, 41, 17-18.

Crutzen, P. (2002). Geology of mankind. Nature, 415, 23.

Danielzik, C.-M. (2013). Überlegenheitsdenken fällt nicht vom Himmel. Postkoloniale Perspektiven auf Globales Lernen und Bildung für nachhaltige Entwicklung. ZEP (Zeitschrift für internationale Bildungsforschung und Entwicklungspädagogik), 36(1), 26-33.

DGfG (Deutsche Gesellschaft für Geographie). (2020). Bildungsstandards im Fach Geographie für den Mittleren Schulabschluss - mit Aufgabenbeispielen. Retrieved from http://geographiedidaktik.org/wp-content/uploads/2020/09/Bildungsstanda rds_Geographie_2020_Web.pdf

Felgenhauer, T. (2007). Geographie als Argument. Eine Untersuchung regionalisierender Begründungspraxis am Beispiel "Mitteldeutschland". Stuttgart: Franz Steiner Verlag.

Fridrich, C. (2013). Von der befremdlichen Persistenz der Länderkunde im Unterrichtsgegenstand Geographie und Wirtschaftskunde - Ergebnisse einer empirischen Untersuchung. GW-Unterricht, 130, 17-27.

Gläser-Zikuda, M. (2013). Qualitative Inhaltsanalyse in der Bildungsforschung - Beispiele aus diversen Studien. In K. Aguado, L. Heine \& K. Schramm (Eds.), Introspektive Verfahren und qualitative Inhaltsanalyse in der Fremdsprachenforschung (pp. 136159). Frankfurt a.M.: Lang.

Hasse, J. (2006). Bildung für Nachhaltigkeit statt Umweltbildung? Starke Rhetorik schwache Perspektiven. In B. Hiller \& M. Lange, M. (Eds.), Bildung für nachhaltige Entwicklung. Perspektiven für die Umweltbildung: Vorträge und Studien (pp. 29-43). Münster: Zentrum für Umweltforschung der Westfälischen Wilhelms-Universität.

Kehren, Y. \& Winkler, C. (2019). Nachhaltigkeit als Bildungsprozess und Bildungsauftrag. In W. Leal Filho (Ed.), Aktuelle Ansätze zur Umsetzung der UN-Nachhaltigkeitsziele (pp. 373-391). Wiesbaden: Springer Spektrum.

Kowasch, M. \& Lippe, D. F. (2019). Moral impasses in sustainability education? Empirical results from school geography in Austria and Germany. Environmental Education Research, 25(7), 1066-1082.

Kowasch, M. (2017). Resource Exploitation and Consumption in the Frame of Education for Sustainable Development in German Geography Textbooks. RIGEO, 7(1), 48-79.

Kuckuck, M. \& Lindau, A.-K. (2020). Wirklichkeit oder Wunschdenken? BNE im Geographieunterricht - Studierende forschen in der Schulpraxis. In A. Keil, M. Kuckuck \& M. Faßbender (Eds.), BNE-Strukturen gemeinsam gestalten. Fachdidaktische Perspektiven und Forschungen zu Bildung für nachhaltige Entwicklung in der Lehrkräftebildung (pp. 149-166). Münster: Waxmann.

Kuckuck, M. (2014). Konflikte im Raum. Verständnis von gesellschaftlichen Diskursen durch Argumentation im Geographieunterricht. Münster: MV-Verlag.

Marchand, S. (2015). Nachhaltig entscheiden lernen. Urteilskompetenzen für nachhaltigen Konsum bei Jugendlichen. Bad Heilbrunn: Klinkhardt.

Mayring, P. (2000). Qualitative Inhaltsanalyse [28 Absätze]. Forum: Qualitative Sozialforschung / Forum: Qualitative Research, 1(2). doi: 10.17169/fqs-1.2.1089 
MSBL (Ministerium für Schule und Bildung des Landes Nordrhein-Westfalen). (2019). Kernlehrplan für die Sekundarstufe I Gymnasium in Nordrhein-Westfalen. Retrieved from https://www.schulentwicklung.nrw.de/lehrplaene/lehrplan/200/g9_ek_klp_ \%203408_2019_06_23.pdf

MSJK (Ministerium für Schule, Jugend und Kinder NRW). (2003). Zulassung von Lernmitteln. Retrieved from https://www.schulministerium.nrw.de/docs/Schulsystem/Medien/ Lernmittel/Kontext/Zulassung.pdf

Pavlova, M. (2013). Towards using transformative education as a benchmark for clarifying differences and similarities between Environmental Education and Education for Sustainable Development. Environmental Education Research 19(5), 656-672. doi: 10.1080/13504622.2012.736476

Rhode-Jüchtern, T. (2004/2015). Narrative Geographie. Plot, Imagination und Konstitution von Wissen. In T. Rhode-Jüchtern (Ed.), Kreative Geographie. Bausteine zur Geographie und ihrer Didaktik (pp. 237-252). Schwalbach: Wochenschau Verlag.

Rieß, W. (2006). Grundlagen der empirischen Forschung zur Bildung für eine nachhaltige Entwicklung (BNE). In W. Rieß \& H. Apel (Eds.), Bildung für eine nachhaltige Entwicklung. Aktuelle Forschungsfelder und -ansätze (pp. 9-19). Wiesbaden: Verlag für Sozialwissenschaften.

Rivera, M., \& Nanz, P. (2018). Erzählend handeln, Handeln erzählen: Fragen an Narrative Nachhaltiger Entwicklung. In B. Bertelmann \& K. Heidel (Eds.), Leben im Anthropozän: Christliche Perspektiven für eine Kultur der Nachhaltigkeit (pp. 137-148). München: oekom.

Rockström, J., Steffen, W., Noone, K., Persson, A., Chapin, F. S., Lambin, E. F., ... Foley, J. A. (2009). Planetary boundaries: exploring the safe operating space for humanity. Ecology and Society, 14(2), 32.

Rüttinger, L., Treimer, R., Tiess, G., Griestop, L., Schüler, F. \& Wittrock, J. (2014). Fallstudie zu den Umwelt- und Sozialauswirkungen der Gewinnung Seltener Erden in Bayan Obo, China. Berlin: adelphi.

Schlottmann, A. (2005). RaumSprache. Ost-West-Differenzen in der Berichterstattung zur deutschen Einheit. Eine sozialgeographische Theorie. Stuttgart: Franz Steiner Verlag.

Schneidewind, U. (2019). Die große Transformation. Eine Einführung in die Kunst gesellschaftlichen Wandels. Frankfurt a. M.: S. Fischer Verlag.

Schuler, S. \& Kanwischer, D. (2013). Bildung für nachhaltige Entwicklung: Globales Lernen und Umweltbildung im Geographieunterricht. In D. Kanwischer (Ed.), Geographiedidaktik. Ein Arbeitsbuch zur Gestaltung des Geographieunterrichts (pp. 164-175). Stuttgart: Borntraeger.

Selby, D. \& Kagawa, F. (2010). Runaway Climate Change as Challenge to the 'Closing Circle' of Education for Sustainable Development. Journal of Education for Sustainable Development, 4(1), 37-50.

Singer-Brodowski, M. (2016). Transformative Bildung durch transformatives Lernen. Zur Notwendigkeit der erziehungswissenschaftlichen Fundierung einer neuen Idee. Zeitschrift für internationale Bildungsforschung und Entwicklungspädagogik, 39(1), 13-17.

Steffens, G. (2010). Politik und Geschichte: "Narrativität" und "Diskursivität" und ihr gemeinsames Drittes. In I. Juchler (Ed.), Kompetenzen in der politischen Bildung (pp. 59-69). Frankfurt a. M.: Wochenschau Verlag. 
Pettig, F.; Kuckuck, M. (2021). Narratives of sustainability on energy-related topics: empirical...

TMBWK (Thüringer Ministerium für Bildung, Wissenschaft und Kultur). (2012). Lehrplan für den Erwerb der allgemeinen Hochschulreife, Geografie. Retrieved from https://www.schulportal-thueringen.de/web/guest/lehrplaene/gymnasium

Vare, P. \& Scott, W. (2007). Learning for a change: Exploring the Relationship Between Education and Sustainable Development. Journal of Education for Sustainable Development, 1(2), 191-198.

Wals, A. E. J., Geerling-Eijf, F., Hubeek, F., van der Kroon, S. \& Vader, J. (2008). All Mixed Up? Instrumental and Emancipatory Learning Toward a More Sustainable World: Considerations for EE Policymakers. Applied Environmental Education and Communication, 7(3), 55-65.

WBGU (Wissenschaftlicher Beirat der Bundesregierung Globale Umweltveränderungen). (2011). Welt im Wandel. Gesellschaftsvertrag für eine Große Transformation. Retrieved from https://www.wbgu.de/fileadmin/user_upload/wbgu/publikationen/hauptgut achten/hg2011/pdf/wbgu_jg2011.pdf

\section{Biographical Statements}

Fabian PETTIG is assistant professor in the Department of Geography and Regional Science at University of Graz, Austria. His research interests revolve around educational theory, emancipatory perspectives on sustainable development and educational implications of digital cultures.

Miriam KUCKUCK is professor in the Institute of Geography and Primary social and science education at University of Wuppertal, Germany. Her research interests are in the field of education for sustainable development, political education and migration.

\section{Appendix}

\section{Analyzed Geography Textbooks And Editions For Secondary Schools}

\begin{tabular}{|c|c|c|}
\hline Code & Title (years2), publisher, release & pages (energy issues) \\
\hline \multicolumn{3}{|c|}{ Thuringia } \\
\hline TH1 & Unsere Erde (5/6), Cornelsen, 2015 & $202(10,9 \%)$ \\
\hline TH2 & Unsere Erde (7/8), Cornelsen, 2013 & $215(9,3 \%)$ \\
\hline TH3 & Unsere Erde (9/10), Cornelsen, 2014 & $133(12 \%)$ \\
\hline TH4 & TERRA Geographie (5/6), Klett, 2012 & $210(4,8 \%)$ \\
\hline TH5 & TERRA Geographie (7/8), Klett, 2013 & $188(10,6 \%)$ \\
\hline TH6 & TERRA Geographie (9/10), Klett, 2014 & $162(3,7 \%)$ \\
\hline TH7 & Seydlitz Geographie (5/6), Westermann, 2012 & $190(10,5 \%)$ \\
\hline TH8 & Seydlitz Geographie (7/8), Westermann, 2012 & $206(12,6 \%)$ \\
\hline TH9 & Seydlitz Geographie (9/10), Westermann, 2012 & $188(9,6 \%)$ \\
\hline
\end{tabular}

2 Years 5/6 equal age 11-12; years 7/8 equal age 13-14; years 9/10 equal age 14-15. 


\begin{tabular}{lll}
\hline \hline North Rhine-Westphalia & \\
\hline NRW1 & Diercke Praxis $1(5 / 6)$, Westermann, 2019 & $178(3,2 \%)$ \\
NRW2 & Diercke Praxis 2 (7/8), Westermann, 2020 & $198(6,1 \%)$ \\
NRW3 & TERRA 1 (5/6), Klett, 2019 & $196(2 \%)$ \\
NRW4 & TERRA 2 (7/8), Klett, 2020 & $206(0,9 \%)$ \\
NRW5 & Seydlitz Geographie $1(5 / 6)$, Westermann, 2020 & $189(2,1 \%)$ \\
NRW6 & Seydlitz Geographie $1(7 / 8)$, Westermann, 2020 & $188(3,2 \%)$ \\
\hline
\end{tabular}

